\title{
DESCRIPTION OF DEMENTIA IN THE ELDERLY STATUS IN THE WORK AREA HEALTH CENTER IBRAHIM ADJIE BANDUNG
}

\author{
Citra Windani Mambang Sari ${ }^{1}$, Eka Fitri Ningsih ${ }^{1}$, Sri Hartati Pratiwi ${ }^{1}$ \\ ${ }^{1}$ Fakultas Keperawatan Universitas Padjadjaran \\ e-mail: citra.windani@unpad.ac.id.
}

\begin{abstract}
Introduction : Number of elderly in Indonesia in 2014 was reached 18.8 million lives and in 2025 would reached 36 million lives. Along with the increasing age, change of cognitive function on elderly was increased. Impaired cognitive function on elderly may caused alteration on personality and disrupting daily activity. If it took progressively, they can lead to dementia. By knowing dementia status on elderly in society it may be used as a database on developing program that related with elderly health in society. The aim this research was to achieve description of dementia status on elderly in society. Method : that used on this research was descriptive with quantitative approaches. Data collected by using Early Dementia Questionnaire (EDQ) on 98 elderlies took by used stratified random sampling technique at Puskesmas Ibrahim Adjie work area Bandung city. Univariat analysis has done to saw description of dementia status on elderly based on respondent characteristic. Result : of this research obtained as many as 38 respondents with presentation $38.8 \%$ experienced early dementia and 60 respondents with $61.2 \%$ respondents belong to normal category
\end{abstract}

Keywords: Dementia, Elderly, Society

\section{PENDAHULUAN}

Jumlah lansia di dunia pada tahun 2015 sebanyak 900,9 juta jiwa dan diperkirakan akan mengalami peningkatan lebih dari $60 \%$ di tahun 2030 yaitu menjadi 1402,4 juta jiwa (United Nations, 2016). Negara Indonesia termasuk dalam salah satu dari lima negara dengan jumlah penduduk lanjut usia terbanyak di dunia. Berdasarkan sensus penduduk pada tahun 2010 jumlah lanjut usia di Indonesia yaitu 18,1 juta jiwa, pada tahun 2014 jumlah penduduk lanjut usia di Indonesia mencapai 18,781 juta jiwa dan diperkirakan pada tahun 2025 jumlah lansia akan mencapai 36 juta jiwa (Kemenkes RI, 2015).

Perubahan pada berbagai sistem dalam tubuh terjadi seiring dengan pertambahan usia seseorang. Perubahan yang mungkin terjadi pada lansia diantaranya adalah perubahan fisik, psikologis, dan perubahan spiritual (Meiner, 2015). Akibat dari perubahan yang terjadi pada lansia adalah menurunnya fungsi kognitif (Lopes, 2016). Penelitian yang dilakukan oleh Dayamaes (2013) dengan metode deskriptif mengenai gambaran fungsi kognitif klien lanjut usia di salah satu posbindu Tanggerang Selatan didapatkan hasil lansia yang mengalami gangguan fungsi kognitif sebanyak 68,06\%. Sedangkan lansia yang memiliki fungsi kognitif normal sebanyak 31,94\%. Gangguan fungsi kognitif pada lansia terjadi umumnya disebabkan oleh gangguan pada sistem saraf pusat yang meliputi gangguan suplai oksigen ke otak, degenerasi, penyakit alzheimer dan malnutrisi. Lansia yang mengalami gangguan fungsi kognitif sering menghadapi berbagai masalah diantaranya gangguan orientasi waktu, ruang, tempat dan tidak mudah menerima ide baru (Maryati et al, 2013). Gangguan fungsi kognitif meliputi atensi, kalkulasi, visuospasial, bahasa, dan memori dapat berakibat terjadi 
perubahan kepribadian, gangguan memori, orientasi, dan sulit mengambil keputusan. Jika hal ini berlanjut secara progresif maka dapat terjadi demensia (William, 2012).

Menurut WHO (2016) demensia adalah gejala terjadinya penurunan memori, berfikir, perilaku, dan kemampuan untuk melakukan aktivitas sehari-hari. Kehilangan kapasitas intelektual pada demensia tidak hanya pada memori atau ingatan saja, tetapi juga pada kognitif dan kepribadian. WHO mencatat tahun 2016 sebanyak 47,5 juta orang di dunia mengalami demensia dan diperkirakan meningkat menjadi 75,6 juta orang di tahun 2030 dan 135,5 juta orang di tahun 2050. Kasus baru demensia terjadi setiap 4 detik dan setiap tahun kejadian demensia terjadi sebanyak 7,7 juta kasus baru. Di Indonesia prevalensi penderita demensia mencapai 606.100 pada tahun 2005, diperkirakan akan meningkat menjadi 1.016 .800 pada tahun 2020 dan 3.042.000 pada tahun 2050 (Rees, Chye, \& Lee, 2006).

Beberapa penelitian memperlihatkan banyaknya lansia yang mengalami demenesia, diantaranya adalah penelitian Hananta dkk (2011) mendapatkan hasil dari 95 responden lansia yang tinggal di 3 panti wherdha wilayah Tanggerang, sebanyak 54 orang mengalami demensia dan 41 orang tidak mengalami demensia. Kuesioner yang digunakan pada penelitian ini adalah mini mental status examination (MMSE), dikatakan demensia jika nilai MMSE < 24. Penelitian Untari (2014) mengukur tingkat demensia pada 60 responden lansia di Panti Wredha Darma Bakti Surakarta, menunjukan hasil lansia dengan kategori demensia berat sebanyak 28 orang $(46,7 \%)$. Selain itu penelitian lain dengan quesioner mental status examination (MMSE) juga dilakukan oleh Maryam dkk (2015) pada 4 Panti Sosial Tresna Wherda yang berada di wilayah Jakarta dengan metode non ekperimen mendapatkan hasil hampir 30\% lansia mengalami demensia.
Demensia dapat dipengaruhi oleh usia, jenis kelamin, riwayat keluarga, diabetes mellitus (DM), hiperkolesterol, obesitas, merokok, alkohol. Demensia dapat dipengaruhi oleh beberapa faktor, baik yang dapat dimodifikasi maupun tidak. Usia, genetik dan riwayat penyakit keluarga merupakan faktor tidak dapat dimodifikasi yang mempengaruhi demensia. Sedangkan faktor yang dapat dimodifikasi terhadap kejadian demensia adalah hipertensi, diabetes mellitus (DM), hiperlipidemia, merokok (Sahathevan, 2015).

Gejala demensia yang terjadi pada lansia dapat dilihat dari beberapa domain. Demensia dini (early dementia) terdiri dari beberapa domain antara lain adalah memori, konsentrasi, gejala fisik, gangguan tidur, dan gejala lainnya (Arabi et al, 2013). Terdapat tiga tahap pada kejadian demensia yaitu tahap awal, tahap pertengahan dan tahap akhir (WHO, 2016).

Demensia yang tidak di deteksi secara dini dan ditangani dengan benar dapat mengakibatkan kematian. Di Beijing, demensia menjadi salah satu faktor penyebab kematian. Setiap tahun 2 dari 100 orang yang berusia 65 tahun ke atas dengan demensia meninggal (Hong Bo et al, 2011). Demensia dapat memberikan pengaruh terhadap aktifitas lansia dalam kehidupan sehari-hari baik di keluarga, lingkungan, pekerjaan dan masyarakat sehingga dapat menyebabkan kualitas hidup menurun (Radhaningsih, 2016). Penurunan kualitas hidup ini disebabkan oleh menurunkan memori, proses berfikir, dan fungsi kognitif pada lansia (Darmojo, 2009). Selain itu, lanjut usia yang mengalami demensia sebagian besar menunjukan gejala perubahan perilaku, mental dan emosi (Seitz et al, 2010). Penelitian Guerra et al (2016) mengemukakan perubahan perilaku ditimbulkan pada lansia yang mengalami demensia diantaranya adalah aktivitas terganggu, terjadi agresi fisik atau verbal gangguan tidur, kecemasan, agresif dan halusinasi.

Lansia yang mengalami demensia 
tidak hanya berdampak pada dirinya sendiri tetapi juga pada keluarga yang merawatnya. Menurut penelitian Widyastuti (2011), lansia dengan demensia memberikan dampak terhadap keluarga yang merawatnya. Respon keluarga dalam merawat lansia demensia sangat beragam, salah satunya menimbulkan beban pada keluarga. Beban keluarga dalam merawat lansia yang terindentifikasi adalah beban fisik berupa keluhan fisik dan munculnya penyakit baru pada keluarga yang merawat lansia, beban psikologi seperti rasa marah pada lansia, beban ekonomi dan beban sosial. Keluarga yang merawat demensia memiliki beban yang tinggi karena membutuhkan biaya dan ketergantungan yang tinggi (Wang, 2012).

Perawat memiliki peran terhadap kelompok lanjut usia yang ada di komunitas (Mubarak \& Chayatin, Ilmu Keperawatan komunitas, 2009). Pengkajian demensia pada lansia di komunitas membantu perawat mengidentifikasi kebutuhan, mengklarifikasi masalah dan mengidentifikasi kekuatan yang ada pada lansia (Stanhope, 2006).

Berdasarkan studi pendahuluan yang peneliti lakukan cakupan kunjungan lansia pada posbindu di wilayah Kerja Puskesmas Ibrahim Adjie Kota Bandung sebesar $23 \%$, sedangkan target sasaran lansia yang datang ke posbindu sebanyak 58\%. Peneliti melihat pada laporan bulanan lansia dari Dinas Kesehatan Kota Bandung sampai dengan bulan Juni 2016 tidak ditemukannya data yang terkait dengan demensia pada lanjut usia. Jika demensia dideteksi dan dicegah sejak dini dapat membuat lanjut usia tersebut hidup dengan optimal dengan kualitas hidup yang baik (WHO, 2016).

\section{METODE}

Populasi dalam penelitian ini adalah seluruh lansia yang tinggal di wilayah kerja Puskesmas Ibrahim Adjie Kota Bandung yaitu di Kelurahan
Cibangkong, Kelurahan Kebon Gedang dan Kelurahan Kebon Waru. Teknik pengambilan sampel yang digunakan secara stratified random sampling dengan jumlah 98 responden.

Instrumen yang digunakan dalam penelitian ini dari Arabi et al (2013) yaitu Early Dementia Questionnaire (EDQ). Hasil dari kuesioner EDQ pada lansia dikategorikan menjadi 2 yaitu kategori normal dengan total skor berjumlah 0-7 dan kategori early dementia dengan total skor 8-60. Kuesioner terdiri dari 20 pertanyaan menggunakan skala likert yang setiap pertanyaan terdiri dari empat pilihan jawaban (tidak pernah, jarang, sering, dan selalu). Cara penilaian demensia menggunakan kuesioner denganskor tidak pernah $=0$, jarang $=1$, sering $=2$, dan selalu $=3$. Hasil uji validitas instrumen memiliki koefisien validitas antara 0,342-0,873 dan nilai reabilitas instrumen yang didapat adalah 0,923 . Analisis penelitian menggunakan analisis deskriptif. Analisis data yang digunakan yakni univariat. Analisis univariat dilakukan pada data dari variabel status demensia berdasarkan karakteristik individu. Penelitian dilakukan di wilayah kerja Puskesmas Ibrahim Adjie Kota Bandung dan pengambilan data dilakukan Tanggal 5-14 Januari 2017.

\section{HASIL}

Tabel 1 menunjukan bahwa sebagian besar responden berada pada umur 60 - 74 tahun sebanyak 66 responden. Berdasarkan jenis kelamin dari responden, didapatkan hasil responden dengan jenis kelamin laki-laki sebanyak 27,6 \%, sedangkan responden dengan jenis kelamin perempuan sebanyak 72,4 $\%$. Berdasarkan status pernikahan responden yang menikah sebanyak 48 responden. Dilihat dari tingkat pendidikan sebagian besar responden berada pada tingkat pendidikan tamat SD yaitu 52 responden. Berdasarkan pekerjaan dari responden, sebanyak 68 responden tidak bekerja. Dilihat 
dari dengan siapa responden tinggal paling besar responden tinggal dengan anak yaitu sebanyak 46,9 \% dan ada responden yang tinggal sendirian sebanyak $11,2 \%$.

\begin{tabular}{lcc}
\hline \multicolumn{1}{c}{ Karakteristik } & F & (\%) \\
\hline Usia & & \\
60 tahun -74 tahun & 66 & 67,3 \\
75 tahun - 90 tahun & 32 & 32,7 \\
Jenis Kelamin & & \\
Laki-laki & 27 & 27,6 \\
Perempuan & 71 & 72,4 \\
Suku & & \\
Sunda & 83 & 84,7 \\
Jawa & 14 & 14,3 \\
Batak & 1 & 1 \\
Status Pernikahan & 1 & 1 \\
Belum Menikah & 48 & 49 \\
Menikah & 3 & 3,1 \\
Bercerai & 46 & 46,9 \\
Janda/Duda & & \\
Pendidikan & 6 & 6,1 \\
Tidak Sekolah & 52 & 53,1 \\
SD & 24 & 24,5 \\
SLTP & 16 & 16,3 \\
SLTA & & 13,3 \\
Pekerjaan & 13 & 69,4 \\
Bekerja & 68 & 17,3 \\
Tidak bekerja & 17 & 11,2 \\
Pensiunan & & 27,6 \\
Tempat Tinggal & 11 & 46,9 \\
Sendirian & 27 & 14,3 \\
Dengan Pasangan & 46 & \\
Dengan Anak & 14 & \\
Dengan Keluarga Besar & & \\
&
\end{tabular}

Tabel 1. Distribusi Berdasarkan Karakteristik Demografi Responden di Wilayah Kerja Puskesmas Ibrahim Adjie Kota Bandung $(n=98)$

Tabel 2 menunjukan pada variabel riwayat merokok sejumlah 12 responden pernah merokok tapi sudah berhenti, 13 reponden masih merokok dan 73 responden tidak pernah merokok. Dilihat dari riwayat hipertensi pada tabel diatas responden yang memiliki riwayat hipertensi yaitu sebanyak 42 responden, untuk riwayat diabetes mellitus sebagian besar responden yaitu 89 responden tidak memiliki riwayat diabetes mellitus, 6 responden memiliki riwayat diabetes mellitus. Pada variabel riwayat kolesterol sebanyak 70 responden tidak memiliki riwayat kolesterol dan 21 responden memiliki riwayat kolesterol. Berdasarkan riwayat stroke dan riwayat keluarga yang mengalami pikun yaitu sebanyak 7 responden memiliki riwayat stroke, dan sebagian kecil responden memiliki keluarga yang mengalami pikun yaitu sejumlah 11 responden. Dilihat dari karakteristik olah raga sebagian besar responden melakukan olah raga berjalan kaki yaitu sebanyak 60 responden, responden yang berolah raga lari sebanyak 15 responden dan 19 responden tidak pernah olah raga. 


\begin{tabular}{|c|c|c|}
\hline Karakteristik & $\mathbf{F}$ & $(\%)$ \\
\hline \multicolumn{3}{|l|}{ Riwayat Merokok } \\
\hline Tidak pernah & 73 & 74,5 \\
\hline Pernah tapi sudah berhenti & 12 & 12,2 \\
\hline Masih merokok & 13 & 13,3 \\
\hline \multicolumn{3}{|l|}{ Riwayat Hipertensi } \\
\hline $\mathrm{Ya}$ & 42 & 42,9 \\
\hline Tidak & 53 & 54,1 \\
\hline Tidak Tahu & 3 & 3,1 \\
\hline \multicolumn{3}{|l|}{ Riwayat Diabetes Mellitus } \\
\hline $\mathrm{Ya}$ & 6 & 6,1 \\
\hline Tidak & 89 & 90,8 \\
\hline Tidak Tahu & 3 & 3,1 \\
\hline \multicolumn{3}{|l|}{ Riwayat Kolesterol } \\
\hline $\mathrm{Ya}$ & 21 & 21,4 \\
\hline Tidak & 70 & 71,4 \\
\hline Tidak Tahu & 7 & 7,1 \\
\hline \multicolumn{3}{|l|}{ Riwayat stroke } \\
\hline $\mathrm{Ya}$ & 7 & 7,1 \\
\hline Tidak & 91 & 92,1 \\
\hline \multicolumn{3}{|l|}{ Riwayat Keluarga Mengalami } \\
\hline \multicolumn{3}{|l|}{ Pikun } \\
\hline Ya & 11 & 11,2 \\
\hline Tidak & 78 & 79,6 \\
\hline Tidak Tahu & 9 & 9,2 \\
\hline \multicolumn{3}{|l|}{ Olah Raga } \\
\hline Tidak Pernah & 19 & 19,4 \\
\hline Berjalan & 60 & 61,2 \\
\hline Lari & 1 & 1 \\
\hline Senam & 15 & 15,3 \\
\hline Bersepeda & 2 & 2 \\
\hline Lainnya & 1 & 1 \\
\hline
\end{tabular}

Kerja Puskesmas Ibrahim Adjie Kota Bandung ( $\mathrm{n}=98)$

\begin{tabular}{lcc}
\hline Variabel & f & \% \\
\hline Early Dementia & 38 & 38,8 \\
Normal & 60 & 61,2
\end{tabular}

Tabel 3. Distribusi Responden Berdasarkan Status Demensia di Wilayah Kerja Puskesmas Ibrahim Adjie kota Bandung ( $\mathrm{n}=98)$ 


\begin{tabular}{|c|c|c|c|c|c|}
\hline \multirow[b]{2}{*}{ Variabel } & \multicolumn{4}{|c|}{ Skor EDQ } & \multirow[b]{2}{*}{ Tota } \\
\hline & $\begin{array}{c}\text { Normal } \\
\text { (f) }\end{array}$ & $\%$ & $\begin{array}{c}\text { Early dementia } \\
\text { (f) }\end{array}$ & $\%$ & \\
\hline \multicolumn{6}{|l|}{ Usia } \\
\hline 60 tahun -74 tahun & 40 & 60,6 & 26 & 39,4 & 66 \\
\hline 75 tahun - 90 tahun & 20 & 62,5 & 12 & 37,5 & 32 \\
\hline \multicolumn{6}{|l|}{ Jenis Kelamin } \\
\hline Laki-laki & 18 & 66,7 & 9 & 33,3 & 27 \\
\hline Perempuan & 42 & 59,1 & 29 & 40,9 & 71 \\
\hline \multicolumn{6}{|l|}{ Status Pernikahan } \\
\hline Belum Menikah & 1 & 100 & 0 & 0 & 1 \\
\hline Menikah & 31 & 64,6 & 17 & 35,4 & 48 \\
\hline Bercerai & 0 & 0 & 3 & 100 & 3 \\
\hline Janda/Duda & 28 & 60,9 & 18 & 39,1 & 46 \\
\hline \multicolumn{6}{|l|}{ Pendidikan } \\
\hline Tidak Sekolah & 2 & 33,3 & 4 & 66,7 & 6 \\
\hline $\mathrm{SD}$ & 32 & 61,5 & 20 & 38,5 & 52 \\
\hline SLTP & 15 & 62,5 & 9 & 37,5 & 24 \\
\hline SLTA & 11 & 68,7 & 5 & 31,3 & 16 \\
\hline \multicolumn{6}{|l|}{ Pekerjaan } \\
\hline Bekerja & 11 & 84,6 & 2 & 15,4 & 13 \\
\hline Tidak bekerja & 41 & 60,3 & 27 & 39,7 & 68 \\
\hline Pensiunan & 8 & 47,1 & 9 & 52,9 & 17 \\
\hline \multicolumn{6}{|l|}{ Tempat Tinggal } \\
\hline Sendirian & 7 & 63,6 & 4 & 36,4 & 11 \\
\hline Dengan Pasangan & 17 & 63 & 10 & 37 & 27 \\
\hline Dengan Anak & 26 & 56,5 & 20 & 43,5 & 46 \\
\hline Dengan Keluarga Besar & 10 & 71,4 & 4 & 28,6 & 14 \\
\hline
\end{tabular}

Tabel 4 Distribusi Status Demensia Berdasarkan Karakteristik Demografi Pada Lansia di Wilayah Kerja Puskesmas Ibrahim Adjie kota Bandung ( $\mathrm{n}=98)$

Pada tabel 3 didapatkan karakteristik responden berdasarkan status demensia, dengan early dementia sebanyak 38,8\%, sedangkan pada lansia yang normal dengan presentasi $61,2 \%$. Tabel 4 menunjukan 66 responden berusia lanjut (6074 tahun), 32 responden termasuk lanjut usia tua (75-90 tahun.). Dari 66 responden yang berusia lanjut mengalami early dementia sebanyak 26 responden, dan dari 32 responden lanjut usia tua, sebanyak 12 responden termasuk kategori early dementia. Berdasarkan jenis kelamin, dari 27 responden laki-laki dan 29 responden perempuan masing-masing ditemukan early dementia (masing-masing 9 responden). Dilihat dari status pernikahan, responden yang berstatus menikah sebanyak 48 responden diantaranya mengalami early dementia (17 responden), sedang responden yang berstatus janda/duda, 18 responden diantaranya mengalami early dementia.

Dari pendidikan, sebagian besar responden berpendidikan SD $(52$ responden), diantaranya mengalami early dementia (20 responden) dan yang berpendidikan SMA (16 responden), hanya 5 yang termasuk early dementia. Berdasarkan pekerjaan, yang paling banyak mengalami early dementia yaitu responden yang tidak bekerja yaitu sejumlah 27 responden Mayoritas lansia tinggal bersama keluarga (46 responden) dan diantaranya terdapat 20 responden mengalami early dementia. 


\begin{tabular}{|c|c|c|c|c|c|}
\hline \multirow[b]{2}{*}{ Variabel } & \multicolumn{4}{|c|}{ Skor EDQ } & \multirow[b]{2}{*}{ Total } \\
\hline & $\begin{array}{l}\text { Normal } \\
\text { (f) }\end{array}$ & $\%$ & $\begin{array}{l}\text { Early dementia } \\
\text { (f) }\end{array}$ & $\%$ & \\
\hline \multicolumn{6}{|l|}{ Riwayat Merokok } \\
\hline Tidak pernah & 40 & 54,8 & 33 & 45,2 & 73 \\
\hline $\begin{array}{l}\text { Pernah tapi sudah } \\
\text { berhenti }\end{array}$ & 9 & 75 & 3 & 25 & 12 \\
\hline Masih merokok & 11 & 84,6 & 2 & 15,4 & 13 \\
\hline \multicolumn{6}{|l|}{ Riwayat Hipertensi } \\
\hline Ya & 26 & 61,9 & 16 & 38,1 & 42 \\
\hline Tidak & 33 & 62,3 & 20 & 37,7 & 53 \\
\hline Tidak Tahu & 1 & 33,3 & 2 & 66,7 & 3 \\
\hline \multicolumn{6}{|l|}{ Riwayat Diabetes Mellitus } \\
\hline $\mathrm{Ya}$ & 5 & 83,3 & 1 & 16,7 & 6 \\
\hline Tidak & 53 & 59,6 & 36 & 40,4 & 89 \\
\hline Tidak Tahu & 2 & 66,7 & 1 & 33,3 & 3 \\
\hline \multicolumn{6}{|l|}{ Riwayat Kolesterol } \\
\hline $\mathrm{Ya}$ & 14 & 66,7 & 7 & 33,3 & 21 \\
\hline Tidak & 43 & 61,4 & 27 & 38,6 & 70 \\
\hline Tidak Tahu & 3 & 42,9 & 4 & 57,1 & 7 \\
\hline \multicolumn{6}{|l|}{ Riwayat stroke } \\
\hline Ya & 5 & 71,4 & 2 & 28,6 & 7 \\
\hline Tidak & 55 & 60,4 & 36 & 39,6 & 91 \\
\hline \multicolumn{6}{|l|}{ Riwayat Keluarga } \\
\hline \multicolumn{6}{|l|}{ Mengalami Pikun } \\
\hline $\mathrm{Ya}$ & 8 & 72,7 & 3 & 27,3 & 11 \\
\hline Tidak & 47 & 60,3 & 31 & 39,7 & 78 \\
\hline Tidak Tahu & 5 & 55,6 & 4 & 44,4 & 9 \\
\hline \multicolumn{6}{|l|}{ Olah Raga } \\
\hline Tidak Pernah & 9 & 47,4 & 10 & 52,6 & 19 \\
\hline Berjalan & 39 & 65 & 21 & 35 & 60 \\
\hline Lari & 1 & 100 & 0 & 0 & 1 \\
\hline Senam & 8 & 53,3 & 7 & 46,7 & 15 \\
\hline Bersepeda & 2 & 100 & 0 & 0 & 2 \\
\hline Lainnya & 1 & 100 & 0 & 0 & 1 \\
\hline
\end{tabular}

Tabel 5 Distribusi Status Demensia Berdasarkan Riwayat Kesehatan Pada Lansia di Wilayah Kerja Puskesmas Ibrahim Adjie kota Bandung.

Tabel 5 menunjukkan bahwa mayoritas responden tidak pernah merokok yakni sebanyak 73 responden, 12 responden pernah merokok tapi sudah berhenti dan 13 responden masih merokok. Dari responden yang tidak pernah merokok 33 responden early dementia dan 40 responden normal. Dilihat dari riwayat hipertensi 42 responden memiliki riwayat hipertensi, dengan 16 diantaranya mengalami early dementia. Responden yang tidak memiliki riwayat hipertensi sebanyak 53 responden, yang memiliki kategori normal 33 responden dan kategori early dementia sebanyak 20 responden. Responden yang memiliki riwayat DM sebanyak 6 responden, dalam kategori normal 5 responden dan 1 responden kategori early dementia. Sedangkan dari 89 responden yang tidak memilki riwayat diabetes mellitus, 33 responden dalam keadaan normal dan 36 responden termasuk early dementia. Dari 21 responden yang memiliki riwayat kolesterol, sebanyak 7 responden kategori early dementia dan 14 responden kategori normal. Dilihat dari riwayat stroke, sebanyak 7 responden memiliki riwayat stroke dengan 5 responden kategori normal dan 2 responden kategori early dementia, sedangkan 91 responden lainnya tidak memiliki riwayat stroke 
dengan responden yang termasuk kategori early dementia sebanyak 36 responden. Status demensia berdasarkan riwayat pikun atau riwayat demensia pada keluarga dari 98 responden, sebanyak 78 responden tidak memiliki riwayat demensia dan 11 responden memiliki riwayat demensia pada keluarga. Dari banyaknya responden yang tidak memiliki riwayat demensia 47 responden kategori normal dan 31 responden kategori early dementia. Responden yang memiliki riwayat demensia pada keluarga, sejumlah 8 responden kategori nomal dan 3 responden kategori early dementia. Dilihat dari aktivitas olahraga, sebagian besar responden melakukan olah raga berjalan kaki yaitu sebanyak 60 yang terbagi 39 responden kategori normal dan 21 responden kategori early dementia. Responden yang tidak pernah berolah raga sejumlah 19 responden, dan 10 responden diantaranya kategori early dementia.

\section{PEMBAHASAN}

Demensia adalah sindrom terjadinya penurunan memori, berpikir, perilaku, dan kemampuan melakukan aktivitas sehari-hari pada individu (WHO, 2016). Dari hasil penelitian didapatkan $38,8 \%$ responden termasuk kategori early dementia. Penelitian yang telah dilakukan Maryam dkk (2015), sebesar 27,5\% lansia yang ada di Panti Sosial Tresna Wherdha Wilayah DKI Jakarta lansia mengalami demensia. Hasil penelitian lain yang telah dilakukan pada lansia yang berada di wilayah Kabupaten Tanggerang yaitu sebanyak 56,84 $\%$ lansia yang mengalami demensia (Hananta dkk, 2011). Perbedaan hasil penelitian ini dapat disebabkan oleh berbagai faktor yang mempengaruhi terjadinya demensia pada lansia antara lain usia, jenis kelamin, genetik, riwayat hipertensi, diabetes mellitus, hiperlipidemia, merokok (Sahathevan, 2015).

Hasil penelitian pada tabel 4 menunjukan bahwa responden yang termasuk kategori early dementia pada usia 60 tahun sampai 74 tahun $(39,4 \%)$ dan pada responden yang berusia 75 tahun sampai 90 tahun $(37,5 \%)$. Penelitian yang dilakukan oleh Maryam, dkk (2015) menyebutkan bahwa lansia yang berusia $>65$ tahun berpeluang untuk terjadi demensia.

Pada hasil penelitian ini sebanyak 9 responden $(33,3 \%)$ berjenis kelamin laki-laki dan sebanyak 29 responden $(40,9 \%)$ berjenis kelamin perempuan termasuk kategori early dementia. Jumlah responden berjenis kelamin perempuan yang termasuk kategori early dementia lebih banyak bisa dikarenakan pada penelitian ini jumlah responden perempuan lebih banyak yaitu sebanyak 2,6 kali lebih banyak. Azad et al (2007). melakukan penelitian membedakan faktor terjadinya demensia antara dua jenis kelamin. Didapatkan hasil bahwa kejadian demensia lebih banyak terjadi pada perempuan.

Dilihat dari status pernikahan, responden yang termasuk kategori early dementia berstatus janda/ duda lebih banyak jika dibandingkan dengan responden yang berstatus menikah. Hasil penelitian ini sejalan dengan penelitian Larasati (2012) menghasilkan responden yang berstatus janda/ duda lebih banyak yang mengalami demensia. Hubungan perkawinan yang baik dapat digunakan sebagai bantuan sosial dalam kehidupan seseorang, diantaranya dalam mengatasi dan mencegah demensia.

Hasil penelitian mendapatkan bahwa sebagian besar responden berada pada tingkat pendidikan sekolah dasar sebanyak 52 responden $(53,1 \%)$. Respoden yang termasuk kategori early dementia sebanyak 4 responden $(66,7 \%)$ tidak bersekolah, 20 responden $(38,5 \%)$ pendidikan SD, 9 responden $(37,5 \%)$ berpendidikan SLTP, dan 5 responden berpedidikan SLTA. Semakin tinggi pendidikan seseorang maka semakin banyak pengetahuan yang didapatkan sehingga 
mereka akan lebih mampu menyadari perubahan yang terjadi dalam dirinya dibandingkan dengan mereka yang berpendidikan lebih rendah. Hal ini juga diungkapkan oleh Lasarati (2012) bahwa semakin rendah pendidikan seseorang maka resiko terjadinya demensia semakin meningkat. Pendidikan mampu mengkompensasi semua tipe neudegenerative dan gangguan vaskuler, dan juga mempengaruhi berat otak. Orang yang berpendidikan lebih lanjut memiliki berat otak yang lebih dan mampu menghadapi perbaikan kognitif dan neurodegenerative dibandingkan dengan orang yang berpendidikan lebih rendah.

Berdasarkan pekerjaan, responden yang bekerja termasuk kategori early dementia sebanyak 2 responden (15,4\%), lebih rendah dari yang tidak bekerja yaitu sebanyak 27 responden $(39,7 \%)$. Sedikitnya responden yang termasuk kategori early dementia pada lansia yang masih bekerja dihubungkan dengan seseorang yang bekerja sering menggunakan otak sehingga terlatih dalam menghadapi perubahan neuro generative pada lansia.

Pada hasil penelitian sebagian besar responden tinggal dengan keluarga, hanya 11 responden yang tinggal sendirian (11,2 \%). Dari responden yang termasuk kategori early dementia, yang tingal sendirian sebanyak 4 responden dan 34 responden tinggal dengan keluarganya. Responden yang tinggal dengan keluarga memungkinkan mendapatkan motivasi, dukungan, perhatian dan penghargaan selama menjalani kehidupannya. Keluarga menjadi pemegang peran penting dalam memberikan perawatan dan dukungan untuk menjaga kualitas hidup lansia, terlebih kualitas hidup lansia yang mengalami demensia (Nugraheni dkk, 2013).

Berdasarkan riwayat hipertensi responden, sebanyak 42 responden memiliki riwayat hipertensi, sebanyak
16 responden $(38,1 \%)$ termasuk kategori early dementia sedangkan $37,7 \%$ responden yang tidak memiliki riwayat hipertensi termasuk kategori early dementia. Sejalan dengan penelitian yang dilakukan Shandy (2014) mendapatkan hasil sebanyak $40 \%$ responden $\mathrm{Hal}$ ini dihubungakan dengan hipertensi meningkatkan resiko penyakit kardivaskular dan serebrovaskular (Sahathevan, 2015).

Penelitian ini menemukan 1 responden yang memiliki riwayat diabetes mellitus (DM) $(16,7 \%)$ menderita early dementia, sedangkan responden yang tidak memiliki riwayat DM sebanyak $36(40,4 \%)$ kategori early dementia. Sedikitnya presentasi responden kategori early dementia dapat disebabkan jumlah responden yang memiliki riwayat DM lebih sedikit yaitu 5 responden $(5,1 \%)$. Salinas (2016) melakukan analisis kejadian demensia pada subjek mengalami DM tipe 2 selama 3 tahun mendapatkan hasil seseorang yang menderita DM tipe 2 beresiko dua kali lipat terjadinya demensia. Kadar gula dalam darah yang tinggi menjadi penyebab gangguan fungsi dan struktur otak Selain itu, presentasi paling tinggi kategori early dementia pada responden yang tidak mengetahui memiliki riwayat kolesterol sebanyak 57,1\%. Sedangkan pada riwayat stroke, sebanyak 2 responden $(28,6 \%)$ termasuk kategori early dementia. Hiperlipidemia dan stroke dapat menggangu suplai darah ke otak dapat menyebabkan kehilangan neuron dan akson yang terakumulasi terus menerus menjadi lesi di otak (Holmes, 2016).

Berdasarkan hasil penelitian pada karakteristik riwayat pikun / demensia, pada responden yang tidak memiliki riwayat pikun sebanyak 31 responden $(39,7 \%)$ kategori early dementia dan 47 responden $(60,3 \%)$ kategori normal. Responden yang memiliki riwayat pikun pada keluarga, 3 responden $(27,3 \%)$ kategori early dementia dan 8 responden $(72,7 \%)$. Pada penelitian ini responden yang memiliki riwayat 
demensia pada keluarga lebih sedikit dapat dikarenakan responden menganggap gejala demensia sebagi penuaan normal biasa. Terjadinya perubahan jumlah, struktur dan fungsi neuron di daerah tertentu dari korteks otak mengakibatkan mutasi dari tiga gen (amyloid precursor protein, presenilin I dan presenilin 2) meningkatkan produksi $\beta$-amiloid (dari 40 asam amino menjadi 42 asam amino). Struktur ekstraseluler yang besar sebagai plak yang terjadi pada demensia (Holmes, 2016).

Hasil penelitian diketahui bahwa sebanyak $52 \%$ responden mengalami early dementia adalah pasien yang tidak banyak olahraga. Olah raga berjalan ini dihubungkan dengan aktifitas fisik lansia. Lansia yang melakukan aktifitas fisik berjalan berpengaruh terhadap mencegah penurunan daya kerja otak pada lanjut usia. Olahraga berjalan mampu meningkatkan aliran darah ke otak sehingga pembuluh darah terstimulasi dan akses otak mendapatkan energi dan oksigen meningkat (Effendi, dkk, 2014).

\section{KESIMPULAN}

Penelitian ini menyimpulkan bahwa lansia yang termasuk kategori early dementia dengan presentasi 38,8 $\%$ dan lansia yang termasuk kategori normal dengan presentasi $61,2 \%$. Berdasarkan karakteristik responden kategori early dementia pada usia 60-74 tahun sebanyak 26 responden $(39,4 \%)$, jenis kelamin perempuan sebanyak 29 responden $(40,9 \%)$ dan pada pendidikan Sekolah Dasar sebanyak 20 responden (38,5\%).

\section{DAFTAR PUSTAKA}

Arabi, Z., Aziz, N. A., Razali, R., \& Puteh, S. E. (2013). Early Dementia Questionnaire (EDQ): A new screening instrument for early dementia in primary care practice. BMC Family Practice http://www. biomedcentral.com/1471-2296/14/49.

Azad, N. A., Bugami, M. A., \& Loy, I. (2007). Gender Differences in Dementia Risk Factors. Gender Medicine/ Vol. 4, No 2, 120-126.

Darmojo, B. (2009). Geriatri (Ilmu kesehatan
Lanjut Usia). Jakarta: Balai Penerbit FKUI.

Dayamaes, R. (2014). Gambaran Fungsi Kognitif Klien Usia Lanjut di Posbindu Rosela Legoso Wilayah Kerja Puskesmas Ciputat Timur tanggerang Selatan.

Alzheimer's Association. Published by Elsevier Inc., 1-10.

Guerra, J. J., Rodriguez, J. J., Hermandez, M. A., Guerra, J. C., Salgado, A. M., Guerrero, E. P., \& Pelnaver, A. I. (2016). Behavioral and Psychological Symptoms in Elderly Patients With Dementia. International Journal of Psychophysiology volume 108, 110.

Hermana. (2008). Jangan Sia-Siakan Lansia. Retrieved 09 24, 2016, from www.kemsos. go.id

Hernawati, I. (2006). Pedoman Tatalaksana Gizi Usia Lanjut Untuk Tenaga Kesehatan . Jakarta: Depkes.

HongBo, Z., Xin, Z. Z., JueBin, H., LeiLei, D., \& QingHua, W. (2011). Mortality of Dementia and Its Subtypes in Urban and Rural Communities of Beijing. Biomed Environ Sci, 483-490.

Kindall. (2015). Medical Surgical Nursing. Bandung: EGC.

Leuckenotte, A. (2006). Gerontologic Nursing. Mosby: St. Louis.

Lopes, M. A., Xavier, A. J., \& D’Orsi, E. (2016, juni 3). Cognitive and functional impairment in an older community. Archives of Gerontology and Geriatrics, pp. 134-139.

Maryam, R. S., Ekasari, M. F., Rosidawati, Jubaedi, A., \& Batubara, I. (2008). Mengenal Usia Lanjut dan Perawatannya. Jakarta: Salemba Medika.

Maryam, R. S., Hartini, T., \& Sumijatun. (2015). Hubungan Tingkat Pendidikan dan Aktivity Daily Living Dengan Demensia pada lanjut Usia di Panti Werdha. Jakarta.

Maryati, H., Bhakti, D. S., \& Dwiningtyas, M. (2013). Gambaran Fungsi Kognitif Pada Lansia di UPT Panti Werda Mojopahit. Mojokerto: http://www. stikespemkabjombang.ac.id/ejurnal/ index.php/April-2013/article/ viewFile/17/15.

Meiner, S. E. (Mosby Elsevier). Gerontologic Nursing. (5rd Edition). St Louis, Missouri: Mosby Elsevier.

Mongisidi, R. (2012). Profil Penurunan Kognitif Pada Lansia di Yayasan-Yayasan Manula di Kecamatan Kawangkoam.

Mubarak, W. I., \& Chayatin, N. (2009). Ilmu Keperawatan komunitas. Jakarta: salemba Medika.

Mubarak, W. I., \& Chayatin, N. (2009). Ilmu Keperawatan Komunitas Pengantar dan Teori. Jakarta: Salemba Medika.

Rees, G., Chye, A. P., \& Lee, S. H. (2006). Dementia In The Asia Fasific Region The Epidemic Is Here. Retrieved from 
http://www.alz.org.sg/sites/alz. org.sg/files / Publications\%20-\%20 AsiaPacificEpidemicSept06\%20-\%20 Exec\%20Summary.pdf

Sahathevan, R. (2015). Dementia: An Overview of Risk Factors. Kuala Lumpur: Universiti Kebangsaan Malaysia Medical Centre (UKMMC).

Seitz, D., Purandare, N., \& David, C. (2010). Prevalence of psychiatric disorders among older adults Prevalence of psychiatric disorders among older adults. International Psychogeriatrics 22, 10251039.

Shandy, P. P. (2015). Prevalensi suspek demensia pada lansia dengan hipertensi di wilayah kerja UPT Puskesmas Banjarangkan Tahun 2015. Bali: https:// wisuda.unud.ac.id/pdf/1002006111-1jurnal\%20lengkap\%20pinky.pdf.

Stanhope, M. (2006). Fondations of Nursing In The Community.

Sunaryo, Wijayanti, R., Kuhu, M. M., Sumedi, T., Widayanti, E. D., Sukrilah, U. A., . . . Kuswati, A. (2016). Asuhan Keperawatan Gerontik. Yogyakarta: CV. Andi Offset.
Sunaryo, Wijayanti, R., Kuhu, M. M., Sumedi, T., Widayanti, E. D., Sukrillah, U. A., . . . Kuswati, A. (2016). Asuhan Keperawatan gerontik. Yogyakarta: CV. Andi Offset.

United Nations . (2016). World Population Aging. United Nations Department of Economic and Social Affairs.

Untari, I. (2014). Kajian Tingkat Dimensia di Panti Wredha Darma Bakti Surakarta.

Wang, K. Y. (2012). The care burden of families with members having intellectual and developmental disorder: a review of the recent literature. Curr Opin Psychiatry 25, 348-352.

WHO. (2016). Dementia. Retrieved from http:/ / www.who.int/mediacentre/factssheets / fs362/en/

Widyastuti, R. H. (2011). Gambaran Beban Keluarga dalam Merawat Lansia Dengan Demensia di Kelurahan Pancoran Mas, Depok, Jawa Barat: Studi Fenomenologi. Purwokerto: http://eprints.undip. ac.id/37477/.

Williams, P. (2012). Basic Geriatric Nursing. China: Elsevier. 